2003-01-01

\title{
Substratum heterogeneity of dredged vs un-dredged maerl grounds
}

\author{
Kamenos, NA
}

http://hdl.handle.net/10026.1/1360

$10.1017 / \mathrm{s} 0025315403007264 \mathrm{~h}$

Journal of the Marine Biological Association of the United Kingdom

Cambridge University Press (CUP)

All content in PEARL is protected by copyright law. Author manuscripts are made available in accordance with publisher policies. Please cite only the published version using the details provided on the item record or document. In the absence of an open licence (e.g. Creative Commons), permissions for further reuse of content should be sought from the publisher or author. 


\title{
Substratum heterogeneity of dredged vs un-dredged maerl grounds
}

\author{
N.A. Kamenos $*^{\ddagger}$, P.G. Moore* and J.M. Hall-Spencer ${ }^{\dagger}$ \\ *University Marine Biological Station Millport, Isle of Cumbrae, Scotland, KA28 0EG. ${ }^{\dagger}$ Department of Biological Sciences, \\ University of Plymouth, Drake Circus, Plymouth, PL4 8AA. ${ }^{\ddagger}$ E-mail: nick.kamenos@millport.gla.ac.uk
}

\begin{abstract}
Maerl grounds are comparable to sea grass beds in terms of their high biodiversity, and are characterized by abundant juveniles of species such as the queen scallop, Aequipecten opercularis. Maerl grounds impacted by towed demersal fishing gears are structurally less heterogeneous than pristine, un-impacted maerl grounds, diminishing the biodiversity potential of these habitats.
\end{abstract}

\section{INTRODUCTION}

Maerl grounds are formed from loose-lying, normally non-geniculated, coralline red algae (Corallinaceae). Such grounds are found in areas characterized primarily by high water movements in the photic zone. Maerl grounds form shallow marine biotopes of high biodiversity, analogous to kelp forests and sea grass beds, all of which are habitats created by marine phototrophs (Birkett et al., 1998; BIOMAERL team, 1999). Maerl grounds can be productive areas for the collection of adults and juveniles of commercially important species such as queen scallops (Aequipecten opercularis) (Hall-Spencer, 1998). Gadoids (N.A. Kamenos, personal observation) too, may be attracted by substratum heterogeneity. High habitat heterogeneity is known to equate to high biodiversity in many marine and terrestrial systems (Ormond et al., 1997).

Towed demersal fishing gears, especially scallop dredges, cause major physical disturbance to the seabed. The destructive impact of such gears is particularly marked on biogenic substrata, such as sea grass and maerl grounds (Hall, 1999; Kaiser \& de Groot, 2000). Hall-Spencer \& Moore (2000) have shown that a single passage of towed demersal gear can kill maerl thalli due to burial, but there are no data on the mechanical damage suffered by maerl thalli due to gear impaction.

\section{MATERIALS AND METHODS}

Rapid analytical techniques were utilized to investigate differences in 1-, 2- and 3-dimensional heterogeneity of maerl from impacted and pristine grounds using sand and gravel for comparison.

The Stravanan Bay (Isle of Bute, $55^{\circ} 45.36^{\prime} \mathrm{N} 05^{\circ} 04.29^{\prime} \mathrm{W}$, $-11 \mathrm{~m}$ CD) maerl ground has been impacted by scallop dredgers for at least 20 years (Hall-Spencer \& Moore, 2000) and was selected as the impacted maerl site. The Caol Scotnish (Loch Sween, 56 $01.99^{\prime} \mathrm{N} 05^{\circ} 36.13^{\prime} \mathrm{W},-4$ to $-15 \mathrm{~m} \mathrm{CD}$ ) maerl ground has not been dredged due to its isolated location behind a shallow sill and was selected as the unimpacted site.
Unimpacted live maerl thalli (Figure 1A) were collected by SCUBA diving using hand-held cores. Impacted maerl thalli were mainly dead (Figure 1B) and were collected in a similar manner. Unimpacted maerl thalli were larger (median length $12.8 \mathrm{~mm}$ ) but had similar branch morphology (median diameter $1.7 \mathrm{~mm}$ ) to the impacted maerl thalli (median length $6 \mathrm{~mm}$; medial diameter $1.5 \mathrm{~mm}$ ). Live maerl is protected by the EC Habitats Directive 1992, so deliberate experimental damage to live maerl was avoided. Thus a historically impacted site was selected and assumed to have had similar pre-impaction heterogeneities (for same growth form) to live maerl. Gravel (glacial origin) (median length $9.5 \mathrm{~mm}$; width $5.7 \mathrm{~mm}$ ) was collected from the HWM at Ballochmartin Bay, Isle of Cumbrae $\left(55^{\circ} 47.09^{\prime} \mathrm{N} 04^{\circ} 53.55^{\prime} \mathrm{W}\right)$ and fine grade sand (siliceous) $(125-250 \mu \mathrm{m}$ diameter) from the HWM on Kames Bay, Isle of Cumbrae $\left(55^{\circ} 45.16^{\prime} \mathrm{N} 04^{\circ} 54.57^{\prime} \mathrm{W}\right)$.

Complexity analyses (1-, 2- and 3-plane) were conducted one day after substratum collection, with the substrata being stored in flow-through seawater tanks.

One-Plane Complexity (rugosity): each substratum was placed in a glass-fronted Perspex container $(5 \times 10 \times 2 \mathrm{~cm})$ to mid level and then seawater was added to the top of the container. The container was placed in a white photographic diffusion box to prevent glare and the glass plane photographed perpendicularly with a $\operatorname{Kodak}^{\circledR}$ DC240 digital camera in macro mode, using ambient light and at $1280 \times 960$ pixel image size. Ten replicates of each substratum were set up and photographed. One-plane index (straight line distance/actual distance) for the substratum surface of each replicate was calculated using analySIS ${ }^{\circledR}$ image analysis software (Soft-Imaging Software GmbH) by allowing the software to calculate the actual and straight line distances between two points on the surface of the substratum at 4.8 times magnification (combination of camera and software magnification to allow measurement at the mm scale).

Two-Plane Complexity (area): the glass-fronted Perspex container was filled with each substratum $(\mathrm{N}=10)$ and the interstitial spaces filled with condensed milk, allowing only the solid surfaces in contact with the glass to be seen. The replicates were photographed under the same conditions 


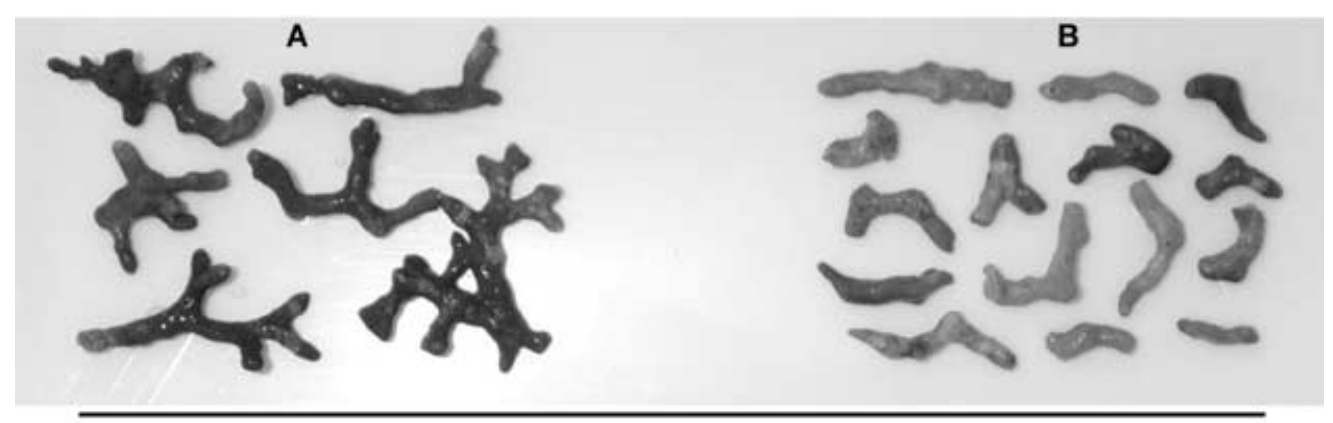

$80 \mathrm{~mm}$

Figure 1. Randomly selected thalli of unimpacted (A) and impacted (B) maerl from Caol Scotnish and Stravanan Bay respectively.

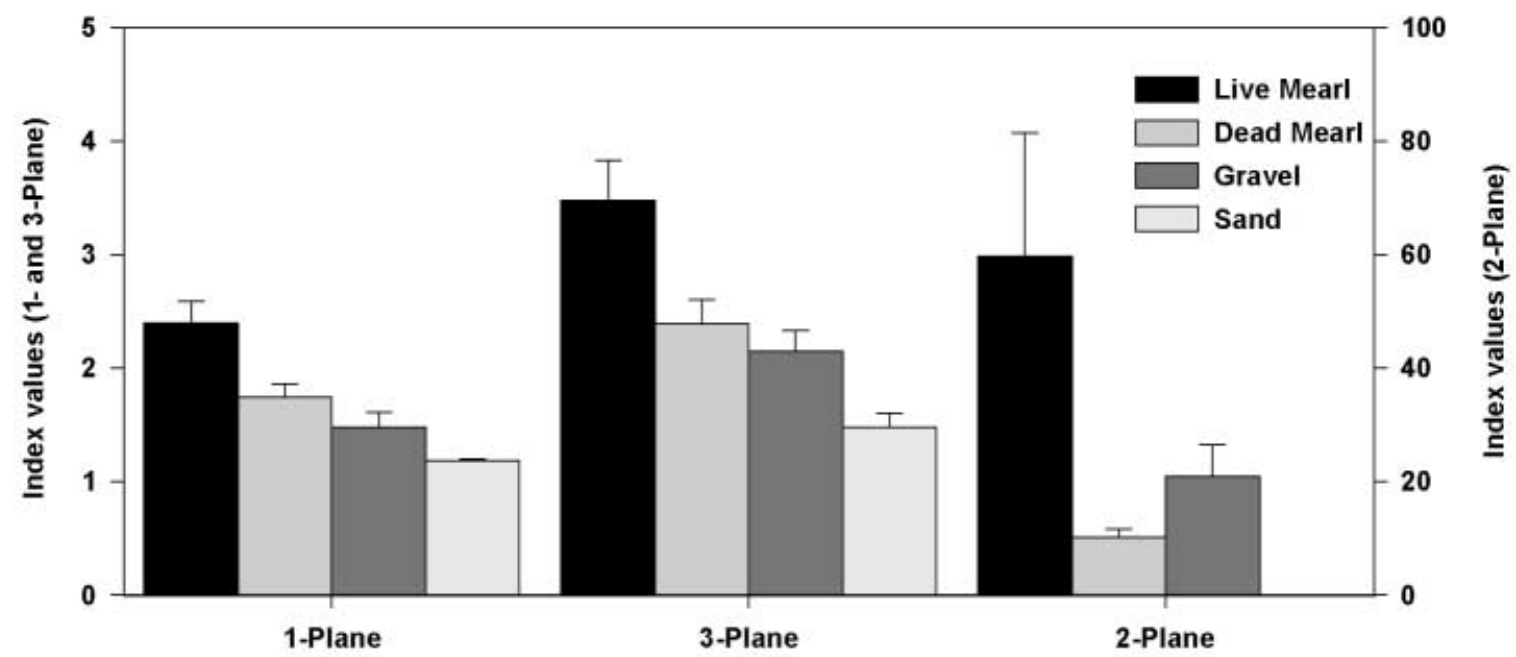

Number of planes included in analysis

Figure 2. One, two and three plane complexity indices on impacted maerl, pristine maerl, gravel and sand. Error bars $=95 \%$ confidence intervals; $\mathrm{N}=10$ for each index (1-plane index =straight line distance/actual distance; 2-plane index =random polygonal area/area of substratum in contact with the glass; 3-plane index $=$ three dimensional volume/substratum volume).

as the 1-plane complexity measures. The images were converted to grayscale using Adobe Photoshop ${ }^{\circledR}$ software. Using analySIS ${ }^{\circledR}$ image analysis software a 2-Plane Complexity Index was constructed as follows: random polygonal area/area of substratum in contact with the glass within the random polygonal area. The area of substratum in contact with the glass was automatically selected by the software at 4.8 times magnification, thus the need for a grayscale image, which removed colour variations between and within the substrata. It was not possible to carry out this analysis using sand as the image resolution was insufficiently high to allow interstitial spaces in the sand to be measured. It is noted that this technique probably calculates lower complexities than present as the thalli and grains are pressed against flat Perspex and not other grains. Plastic impregnation and slicing as used by Bosence (1980) overcomes this, but is a more complex process.

Three-Plane Complexity (volume): all substrata were dried at $80^{\circ} \mathrm{C}$ for 24 hours. Each substratum was placed in a graduated beaker with the uppermost surface protrusions at the $20 \mathrm{ml}$ level. The beaker was subsequently filled to the $30 \mathrm{ml}$ level with seawater, $10 \mathrm{ml}$ were subtracted from the volume used to fill the beaker giving water volume in $20 \mathrm{ml}$ of substratum. Water volume was subtracted from $20 \mathrm{ml}$ to give the substratum volume. Twenty millilitres were then divided by the resultant substratum volume $(\mathrm{N}=10)$. This produced a 3-Plane Complexity Index where higher index values indicated more available matrix space.

\section{RESULTS AND DISCUSSION}

Analysis of variance assumptions were met by all data sets. An ANOVA $(F=103.39, P<0.001, \mathrm{df}=39)$ followed by a Tukey's pairwise comparison indicated that all the substrata had significantly different 1-Plane complexity values. Unimpacted maerl $(2.40 \pm 0.27$ (SD)) had the highest complexity followed by impacted maerl (1.70 $\pm 0.17)$, gravel $(1.48 \pm 0.18)$ and sand $(1.18 \pm 0.02)$ (Figure 2$)$.

An ANOVA $(F=20.49, P<0.001, \mathrm{df}=29)$ followed by a Tukey's pairwise comparison indicated that unimpacted maerl (59.74 \pm 30.44$)$ had significantly higher 2-Plane complexity value than gravel $(20.91 \pm 5.62)$ and dead maerl $(10.14 \pm 1.37)$, which did not differ significantly among themselves (Figure 2). 
An ANOVA $(F=78.63, P<0.001, \mathrm{df}=39)$ followed by a Tukey's pairwise comparison indicated that live maerl $(3.48 \pm 0.5)$ had significantly higher 3-Plane complexity value than gravel $(2.15 \pm 0.27)$ and dead maerl $(2.39 \pm 0.3)$, which did not differ significantly among themselves. Sand $(1.48 \pm 0.16)$ was shown to have significantly lower 3 -Plane complexity than the other substrata. Thus greater matrix space was available for colonization in the live maerl on the millimetre scale (Figure 2).

Unimpacted, pristine maerl had significantly higher structural heterogeneity than dead, impacted maerl, which had similar heterogeneity to gravel. As expected, sand had the lowest heterogeneity. Gear impaction (e.g. scallop dredging) on live maerl grounds reduces substratum heterogeneity (Figure 2), creating an area of maerl resembling a gravel bottom in structure. There is no chance of rapid recovery from such an impact since much of the maerl is killed due to lack of light post-burial (Hall-Spencer, 1998). North-east Atlantic maerl is highly sensitive to demersal gear impacts due to its very slow growth rate (HallSpencer \& Moore, 2000). In Posidonia oceanica beds in the Mediterranean (Ardizzone et al., 2000), which may be seen as a comparable habitat, trawling impacts have also been found to be long-lasting due to damaging key habitatstructuring species with poor regeneration abilities.

All three techniques used in the present study produced rapid results that would allow on-site analysis of the structural complexity of sedimentary habitats. The high biodiversity present on maerl grounds (Birkett et al., 1998; BIOMAERL team, 1999) and their attractiveness as nursery areas are likely to be dependent on substratum heterogeneity. Mechanical damage to maerl (e.g. by commercial extraction, fishing gears, moorings) reduces substratum heterogeneity and would be expected to reduce biodiversity and juvenile settlement and later, recruitment.

\section{REFERENGES}

Ardizzone, G.D., Tucci, P., Somaschini, A. \& Belluscio, A., 2000. Is bottom trawling partly responsible for the regression of Posidonia oceanica meadows in the Mediterrranean Sea? In Effects of fishing on non-target species and habitats: biological, conservation and socio-economic issues (ed. M.J. Kaiser and S.J. de Groot), pp. 37-46. Oxford: Blackwell Science.

BIOMAERL team, 1999. Final Report (in 2 vols.), BIOMAERL Project (Co-ordinator: P.G. Moore, University Marine Biological Station Millport, Scotland), EG Contract No. MAS3-CT95-0020. Pp. 1-541, 542-973 + Appendix.

Birkett, D.A., Maggs, C. \& Dring, M.J., 1998. Maerl (vol. V). An overview of dynamic and sensitivity characteristics for conservation and management of marine SACs. Scottish Association for Marine Science. [UK Marine SACs Project.]

Bosence, D.W.J., 1980. Sedimentary facies, production rates and facies models for recent coralline gravels. Geological fournal, 15, 91-111.

Hall, S.J., ed., 1999. The effects of fishing on marine ecosystems and communities. Oxford: Blackwell Scientific.

Hall-Spencer, J.M., 1998. Conservation issues relating to mearl as habitats for molluscs. Fournal of Conchology (Special Publication), 2, 271-286.

Hall-Spencer, J.M. \& Moore, P.G., 2000. Scallop dredging has profound, long-term impacts on maerl habitats. ICES fournal of Marine Science, 57, 1407-1415.

Kaiser, M.J. \& Groot, S.J. de, ed., 2000. Effects of fishing on nontarget species and habitats: biological, conservation and socio-economical issues. Oxford: Blackwell Science.

Ormond, R.F.G., Gage, J.D. \& Angel, M.A., ed., 1997. Marine biodiversity: patterns and processes. Cambridge: Cambridge University Press.

Submitted 27 May 2002. Accepted 11 November 2002. 